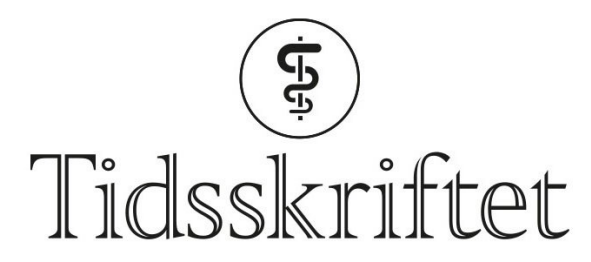

DEN NORSKE LEGEFORENING

\title{
Risiko for opioidmisbruk etter kirurgi
}

FRA ANDRE TIDSSKRIFTER

KETIL SLAGSTAD

Tidsskriftet

For hver gang man fornyer en resept på et opioid legemiddel etter et kirurgisk inngrep, øker risikoen for å utvikle avhengighet.

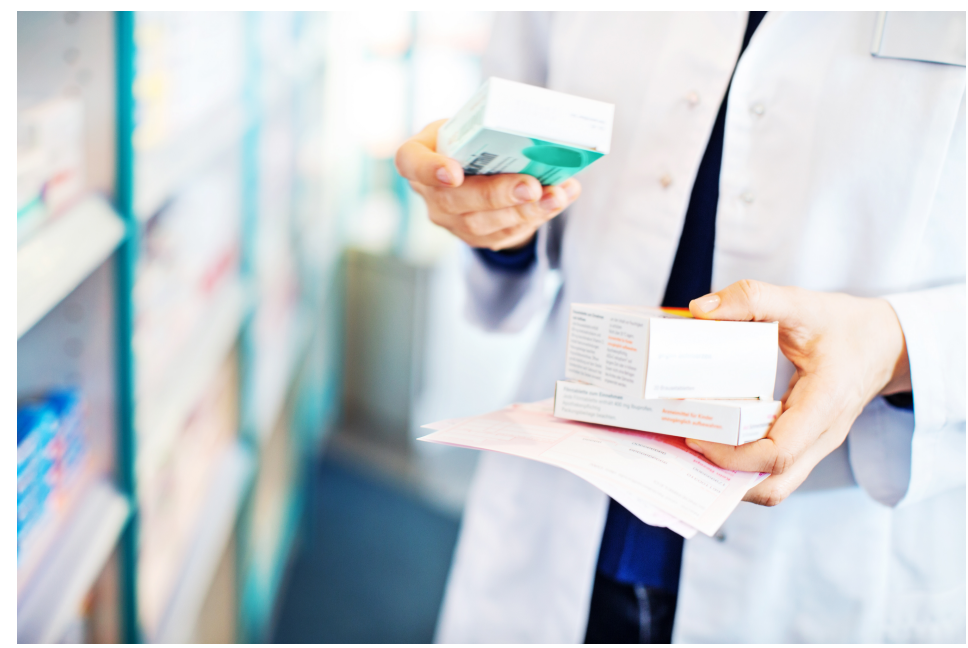

Illustrasjonsfoto: alvarez / iStock

Opioide legemidler mot smerter kan gi avhengighet. Hvor stor er risikoen etter kirurgi? En amerikansk registerstudie, som nylig er publisert i tidsskriftet $B M J$, omfattet over en million mennesker som hadde gjennomgått et kirurgisk inngrep (1). Kun pasienter som hadde brukt opioide legemidler i færre enn åtte dager de siste to månedene, ble inkludert, og pasienter med tidligere opioidavhengighet ble ekskludert.

Om lag halvparten av pasientene hadde fått forskrevet resept på et opioid legemiddel etter inngrepet. I oppfølgingsperioden på median 2,7 år hadde rundt 6 ooo av dem utviklet et misbruk, dvs. o,6\% av alle som gjennomgikk et kirurgisk inngrep. Risikoen for misbruk, definert som at pasienten hadde fått en ICD-9-diagnose, var doblet hos dem som hadde fått fornyet resepten én gang. Risikoen for misbruk var assosiert med lengden på den postoperative smertebehandlingen, og hver reiterering økte risikoen for misbruk. Samtidig bruk av benzodiazepiner eller forskriving av hydromorfon eller oksykodon økte også risikoen. Det samme gjaldt overvektskirurgi, røyking, kroniske smertetilstander og depresjon.

- Denne studien viser at opioide legemidler kan være et tveegget sverd - de lindrer akutte og subakutte smerter godt, men innebærer en snikende risiko for misbruk, sier Harald Breivik, som er professor emeritus i anestesiologi ved Universitetet i Oslo. 
- Opioider er gode midler mot akutte smerter etter kirurgi. Rundt én av ti pasienter som har vært operert, har smerter som varer i mange måneder. Abstinenser som oppstår ved fors $\emptyset \mathrm{k}$ på nedtrapping av dosen, kan føre til forbigående økte smerter. Det kan medføre at opioidforskrivningen fortsetter, sier han. - Risikoen for overdose øker også om opioide legemidler blir kombinert med benzodiazepiner eller Z-hypnotika. Dette må både lege og pasient være oppmerksom på, sier Breivik.

\section{LITTERATUR:}

1. Brat GA, Agniel D, Beam A et al. Postsurgical prescriptions for opioid naive patients and association with overdose and misuse: retrospective cohort study. BMJ 2018;360: j579o. [PubMed][CrossRef]

Publisert: 19. mars 2018. Tidsskr Nor Legeforen. DOI: 10.4045/tidsskr.18.0140 (C) Tidsskrift for Den norske legeforening 2020. Lastet ned fra tidsskriftet.no 